Milica V. Matijević ${ }^{*}$

\title{
TOWARDS A BETTER UNDERSTANDING OF THE STANDARD OF ADEQUATE REPRESENTATION OF PERSONS BELONGING TO NATIONAL MINORITIES IN PUBLIC SECTOR
}

\begin{abstract}
Article 15 of the Framework Convention places an obligation upon the State Parties to provide conditions for the participation of persons of minority origin in the work of their public administration and other segments of the public sector. As it is the case with the other strands of Article 15, the degree of realisation of this duty is measured against the standard of adequate representation. Due to the novel nature of the obligation and the programmatic character of Article 15 the standard of adequate representation in non-elected public bodies has remained underdeveloped and vague. In the paper, the author seeks to identify the legal objectives behind the standard of adequate representation by analysing the Advisory Committee's thematic commentaries and country-specific opinions. The purpose of the paper is to contribute to the further normative elaboration of the standard of adequate representation in a way which would increase its interpretative value.

Keywords: Article 15, standard of adequate representation, public sector bodies, Advisory Committee, national minorities.

\section{Introduction}

Intensive development of international minority law in the last decades of the XX century reached its peak with the adoption of the Framework Convention for the Protection of National Minorities. One of the key provisions of this hard law document is found in its Article 15, which establishes a duty of the State Parties to create conditions for effective participation of persons belonging to national minorities in cultural, social and economic life and in public affairs. This minority rights norm can be seen as an attempt to answer to the recognition $\mathrm{v}$. redistribution dilemma marking the last thirty years of the political and legal theory on equality. ${ }^{1}$ As a simple but eloquent expression of the maxim of "indivisible, interdependent and interrelated" nature of human rights it is meant

\footnotetext{
${ }^{*} \mathrm{PhD}$, Research Fellow, Institute of Comparative Law, Belgrade, Serbia, e-mail: milicavmatijevic@gmail.com.

${ }^{1}$ Here could be worth to mention Nancy Fraser (1997), who was one of the leading proponents of a view that redistribution v. recognition dilemma is a false one and that any meaningful approach to social justice should encompass both aspects of inequality among the groups.
} 
to serve both recognition and redistribution related needs of national minorities. It is at the same time an instrument for the realisation of other minority rights laid down in the Convention and the degree of its fulfilment is an important indicator of the degree of fulfilment of these other rights. ${ }^{2}$

Article 15 places an obligation upon the State Parties to provide conditions for effective participation of persons belonging to minority communities in public affairs of a country. Although the scholarly texts and interpretative documents typically emphasize participation in the elected bodies, the concept of public affairs is here used in the broadest possible sense and includes the non-elected public bodies. Differently from the provisions of Article 25 of the ICCPR, which is to some extent an antecedent of Article 15 and where the concept of public affairs relates to the exercise of political powers, here the notion of public affairs connotes to the wider notion of bodies vested with public powers. ${ }^{3}$ The participatory rights from Article 15 cover all segments of public administration at all levels of its territorial organization, be it international, national, regional and local. ${ }^{4}$

As it is the case with the other Article 15 participatory rights, the level of realisation of the right to participate in public affairs is measured against the standard of adequate representation. The Advisory Committee on the Framework Convention for the Protection of National Minorities ${ }^{5}$ has shaped this particular aspect of the standard into what we could name "the standard of adequate representation of persons belonging to national minorities in public sector". ${ }^{6}$ This subtype of the standard of adequate representation is meant to guide the State Parties and to serve as a benchmark against which the conditions

\footnotetext{
${ }^{2}$ See Advisory Committee on the Framework Convention for the Protection of National Minorities, Commentary No. 2: The Effective Participation of Persons Belonging to National Minorities in Cultural, Social and Economic Life and in Public Affairs, (further: Commentary No. 2), p. 16, para. 3. See also Basta Fleiner, 2013, pp. 19-36.

${ }^{3}$ In Article 25 of the ICCPR, access to public service positions is regulated in a separate subparagraph (Article 25, para. c). In its General Comment No. 25, the Human Rights Committee interprets the conduct of public affairs broadly as the exercise of power in the legislative, executive and administrative branches (General Comment No. 25: The Rights to participate in public affairs, voting rights and the right of equal access to public service (Art. 25), para. 5).

${ }^{4}$ The logical necessity of such a broad conception of the notion of public affairs is even more evident in those interpretations of the scope of Article 15 which do not depart from the types of powers vested on a particular body i.e. from the question whether a body was entrusted with the conduct of public affairs, but from the types of matters at stake. For instance, Malloy et al. (2009, pp. 73-74) refer to "participation in decision-making and self-governance" as the two principal components of the Article 15 right to participation in public affairs, while for Kostadinova (2011, p. 174) the right to effective participation in public life concerns two principal categories: issues affecting minority communities and public affairs of the country as such.

${ }^{5}$ Further: "the Advisory Committee".

${ }^{6}$ The given subtype of the standard of adequate representation is not named as such in the documents produced through the work of the Advisory Committee, but it can be derived from the Advisory Committee's comments on this particular aspect of the Article 15 participatory rights. See, for instance, Second Opinion on Bosnian and Herzegovina, p. 36, para. 200; Second Opinion on Italy, p. 31, para. 136; Second Opinion on Kosovo*, p. 45, paras. 252, 256; Third Opinion on Estonia, p. 39, para. 177; Third Opinion on Italy, p. 40, para. 239; Third Opinion on Serbia, p. 44, para. 181. Apart from the adjective "adequate", the Committee at times also uses the adjective "appropriate" (Second Opinion on Serbia, p. 42, para. 236) or speaks about the "fair number of persons" (Opinion on Cyprus, p. 12, para. 43). In the context of the North Macedonia, the Committee often uses the term "equitable representation", in accordance with the expression used in the national legal framework which guarantees the right to the equitable representation of ethnic communities in the public sector, at central and local levels (Fourth Opinion on North Macedonia, p. 5, para. 4; p. 13, para. 24; p. 19, para. 43, etc).
} 
for the participation of persons of minority origin in the work of public administration and other segments of the public sector are to be reviewed.

Differently from the aspect of the standard which concerns participation in elected public bodies, this second aspect has so far remained almost as vague as the duty for which it is supposed to provide guidance. The experience of Western Balkan countries which received negative findings of the Advisory Committee vis-à-vis the degree of representativeness of their public administrations shows that the standard of adequate representation can be more puzzling then instructive for the governments trying to implement the duty. ${ }^{7}$ Their efforts, because of the vagueness of the very standard they are supposed to meet, often become a bewildering drifting between the cosmetic changes of their legal and institutional set-up and the complex systems of employment quotas. ${ }^{8}$

In this paper, the author examines the objectives behind the standard of adequate representation in non-elected public sector bodies. The paper is based on the premise that a clearer understanding of the objectives behind certain rule or, in this case, standard, is a good method for the more systematic elaboration of its normative content. An answer to the question of why they are expected to create conditions for adequate representation of persons of minority origin in public sector would also equip the State Parties with the clearer view on how they are to realise this obligation. The author charts the objectives behind the standard of adequate representation in the Advisory Committee's thematic commentaries and country-specific opinions. The purpose of the paper is to contribute to the further development of the standard of adequate representation in a way which would increase its interpretative value or, in other words, bring an additional dose of certainty to the standard itself and the process of monitoring conducted by the Advisory Committee.

The structure of the paper is as follows. The author firstly ponders briefly over the nature and the role of the standard of adequate representation. Following that she provides an overview of the most typical references to its objectives as found in the texts of the Advisory Committee. In the central part of the paper, the author translates political notions identified in the previous part into their legal counterparts found in the principle of non-discrimination and the right to identity and then analyses their relationship with the standard of adequate representation. In conclusion, the author summarizes the main findings.

\footnotetext{
${ }^{7}$ For instance, the question of what does "adequate representation" means was one of the most perplexing elements in the considerations of the officials of the Republic of Serbia on how to satisfy this Article 15 requirement and, hence, respond to the findings of the Council of Europe Committee of Ministers that its central level public administration is not enough inclusive (personal experience of the author gained during the participation in the project aimed at providing support to the Government of the Republic of Serbia to improve its legal framework laying down the conditions for the use of affirmative action measures for the employment of persons belonging to national minorities in public sector).

${ }^{8}$ See, for instance: Fourth Opinion on Croatia, p. 33, para. 91; Fourth Opinion on Kosovo*, p. 38, para. 103; Third Opinion on Montenegro, p. 39, paras. 151, 153; Fourth Opinion on North Macedonia, pp. 35-37, paras. 86, 87, 89; Fourth Opinion on Serbia, p. 37, para. 135; p. 38, para. 128.
} 


\section{Briefly on the problem of the incompleteness of the standard of adequate representation}

The paper departs from the view that the standard of adequate representation is a legal standard in the meaning of a rule which specifies the conditions which are necessary for meeting certain legal obligations. A reading of the thematic commentaries and countryspecific opinions on the implementation of the Framework Convention shows that the Advisory Committee uses the standard of adequate representation to interpret the obligations laid down in Article 15 which concern effective participation of persons belonging to minority communities in the work of public sector bodies. As such, the standard of adequate representation should guide the State Parties in their attempt to devise legal and policy strategies which could pave the way towards effective participation of minorities in public affairs and it should serve as a yardstick against which these attempts are to be reviewed.

There are different views in the legal theory on the nature and role of legal standards. ${ }^{9}$ For Dworkin (1977, p. 36), they are those considerations which courts characteristically use when deciding a case, which cannot be derived directly from a legal provision and which "incline decision one way, though not conclusively, and [...] survive intact when they do not prevail". According to Baude \& Sachs (2017, p. 1084), standards or principles make up the "law of interpretation"; "they are pre-existing rules [...] that determine the legal effect of written instruments". Greenberg (2017, p. 114) also recognises the role of standards in determining the content of the law but at the same time insists that they are only one element for the interpretation of the law. Brink (1998, pp. 125-126) observes that "legal interpretation of legal standards involves appeal to underlying principles as well as to the meaning of the words in which the standards are expressed", but that one must beware that purposes or intentions of the framers of a legal standard can be determined at various levels of abstraction.

No matter how we define and what role we assign to legal standards it is indisputable that in order to be useful as the tool of legal interpretation, a legal standard should be to a reasonable degree certain. Certainty here stands for the quality of being reasonably definite and complete. A standard which is uncertain neither provides guidance nor serves the fundamental principle of fairness that all similar cases should be treated alike. ${ }^{10}$

The standard of adequate representation exhibits a low degree of certainty i.e. it can be said that its meaning is neither definite nor complete. To some extent, the vagueness of the standard could be ascribed to the programmatic character of Article 15. The provision of Article 15, as most of the other provisions of the Framework Convention, lacks direct applicability and leaves the States concerned with a broad margin of discretion with regards to the methods for its implementation. This is a logical consequence of the fact that the State Parties exhibit a variety of different contexts and issues to be tackled, for the reason of which it was necessary to give them a wide margin of discretion in the

\footnotetext{
${ }^{9}$ Although these questions are in the legal theory primarily considered in the context of judicial adjudication in the common law systems, given the specific role of the Advisory Committee one can nevertheless draw useful conclusions.

${ }^{10}$ See on this Moore (1969, p. 253), albeit in a completely different context.
} 
implementation of the Framework Convention (Explanatory Report to the Framework Convention for the Protection of National Minorities, p. 12, para. 11). "A measure that leads to effective participation in one State Party", the Advisory Committee notes, "does not necessarily have the same impact in another context" (Commentary No. 2, p. 69, para. 148). Yet, the wide margin of discretion given to the State Parties does not mean that they can meet their Article 15 obligations by mare attempts to achieve therein contained objectives. Despite the high degree of their indeterminateness, the obligations arising from Article 15 are not the obligations of conduct but the obligations of result (Malloy et al., 2009, p. 96). In other words, the State Parties to the Convention should ensure that there is effective participation of persons belonging to national minorities in public affairs, no matter which method they use. This is reflected in the monitoring process as well. Given the nature of obligations placed before the State Parties, the Advisory Committee cannot go beyond what is necessary while giving guidance on their appropriate implementation, nor it could propose concrete solutions, no matter how appropriate they would be for the achievement of the Convention's objectives in a given context. The Advisory Committee can go only thus far as to identify the principal areas of concern for the effective realization of obligations and point to adaptable patterns of best practice by encouraging State Parties to continue with the implementation of certain measures, or by criticizing other measures as ineffective or contrary to the objectives of the Framework Convention.

The second reason for the vagueness surrounding the standard surely lays in the novelty of this type of obligations (Kostadinova, 2011, p. 176). The extent to which the standard of adequate representation of persons belonging to national minorities in public sector is new can be seen in the Advisory Committee's findings from the first monitoring cycle, in which none of the reviewed countries had met the standard when it comes to the executive branch of public bodies (Weller, 2004, p. 289). ${ }^{11}$ This is also observable in the low attention given to this subject-matter in the scholarly literature and in the work of international standard-setting bodies, which are primarily focused on the question of minority representation in elected public bodies and bodies in charge of the issues of special concern for national minorities (See, for instance: Phillips, 2009; Venice Commission, 2011).

What we know from the Advisory Committee commentaries and opinions is that representation of persons of minority origin is an essential (but not sufficient) condition for their effective participation in public affairs. What it takes to fulfil this condition cannot be discerned by recourse to the standard given that the notion of "adequate representation" does not contain any parameters that could answer that question. For that reason, to understand what is meant by an adequate representation of persons of minority communities in public administration bodies we need to understand the legal rationale behind Article 15 and the duty of adequate representation. Why should public administration be representative of the different ethnic groups living in a country? The mainstream human and minority rights discourse is dominated by the notions of diversity, social inclusion, social cohesion, fair and democratic governance, etc. to the point that this question sounds redundant and the answer to it self-evident. As we will see from the

${ }^{11}$ In effect, until fairly recent times the monolingual public administration was the dominant model in most of the European countries. See on this, Malloy \& Wolf, 2016, p. 486. 
following passage, these notions also prevail in the Advisory Committee's interpretations of the objectives behind Article 15 and the standard of adequate representation.

\section{On the broad objectives behind the standard of adequate representation}

The broadly stated goal of preserving and enhancing the diversity of the European societies dominates the Advisory Committee's reflections on the rationale of the standard of adequate representation. "Public administration should, to the extent possible, reflect the diversity of society", says the Commentary on the effective participation of persons belonging to national minorities in cultural, social and economic life and in public affairs from 2008 (p. 8 , para. 120 , p. 31$).{ }^{12}$ The recruitment of persons belonging to national minorities in public administration should be promoted as "a means to [...] attest to the government openness towards diversity in society" (Fourth Opinion on Norway, p. 32, para. 91). This general purpose is then complemented by other similarly broad statements evolving around the goal of social cohesion: "The effective participation of persons belonging to national minorities in various areas of public life is essential to ensure social cohesion and the development of a truly democratic society" (Commentary No. 2, p. 15, para. 1 ) ${ }^{13}$ Good governance, in the meaning of inclusive governance, is another value invoked by the Advisory Committee as an objective behind Article 15 participatory rights. According to the Committee, "[c]reating the conditions for effective participation of persons belonging to national minorities should [...] be considered by the State Parties as forming an integral part of the implementation of the principles of good governance in a pluralistic society" (Commentary No. 2, p. 19, para. 8). The reflections on the purpose of Article 15 are also found in the Advisory Committee's references to the ideal of fairness of governing structures. Public administration should meet needs of all the segments of society, including the specific needs of persons belonging to national minorities, and "the recruitment of persons belonging to minorities into public administration, [...] should be promoted as a means to better respond to their needs" (Fourth Opinion on Finland, p. 32, para. 96). In the Advisory Committee's opinion, this is closely related to the need to secure the true legitimacy of democratic institutions, which can be achieved only if the members of national minorities are treated equally with the members of majority population by accommodating their specific linguistic and other needs (Commentary no. 2, p. 32, para. 1; p. 58, para. 120). Given the more and more pronounced tendency to link human rights goals with economic efficiency, which in the last two decades marks the mainstream human rights discourse, the Committee also refers to the importance of participatory rights to prevent marginalisation of persons belonging to national minorities, which brings "the risk of losing their contribution and additional input to society" (Commentary No. 2, p. 19, para. 9). In the end, the need to ensure effective participation of national minorities in public affairs, including through their adequate representation in public sector bodies, is often

\footnotetext{
${ }^{12}$ See also: Fourth Opinion on Finland, p. 32, para. 96; Fourth Opinion on the Slovak Republic, p. 27, para. 79.

${ }^{13}$ See, similarly, Opinion on the Netherlands, para. 79, para. 83.
} 
linked to the integration of national minorities. ${ }^{14}$ The importance of public administration makes of it a place in which minority languages and cultures need to be specially nurtured as an integral part of mainstream society, including through the employment of persons with the minority background. For that reason, the Advisory Committee notes that prevention of assimilation requires not only removal of policies with the assimilatory effect, but also positive measures that would enable persons belonging to minority communities to preserve and develop their culture (Commentary No. 3, p. 17, para. 79).

We see that the Advisory Committee explains the rationale of the standard of adequate representation of persons belonging to minority communities in public sector bodies through the notions of diversity, social cohesion, democratic governance, inclusive society and integration. Identical remark can be given about the relevant soft law instruments (see OSCE High Commissioner on National Minorities, 1999, 2012). The same can be also said about the scholarly texts on the topic, as most of the authors refer to these notions as to the self-explanatory truths behind the participatory rights laid down in Article 15. While the given notions play an important role of rooting the Article 15 participatory rights in the broader system of values from which they can draw their moral force, the question is to what extent they can be helpful for the further articulation of these rights. How much guidance they can give to the State Parties attempting to understand what is required under the standard of adequate representation and trying to develop, based on such an insight, the legal and policy strategies which would secure the realization of duties enshrined in Article 15? No matter how important is their rhetorical function for the human and minority rights discourse, diversity, social cohesion, good governance, etc. are all political concepts from which the normative content of the standard of adequate representation cannot be derived nor could they guide the practice of the State Parties aimed at its realisation.

\section{In search of the legal rationale of the standard of adequate representation}

Law and politics are closely related fields of social practice with many concepts in common. This is particularly observable in the constitutional texts and international human rights treaties such as the Framework Convention, in which the social ideals and legal justice goals are closely intertwined. Law has its language and its logic determined by the objectives and scope of legal justice and methods of legal interpretation. For that reason, social goals need to be filtered and translated into corresponding legal goals to arrive to their elements which can be preserved and protected through the mechanisms of legal justice. The process of filtering means in the first place that the relationship between the values protected in the newly enacted provisions and those protected in the existing provisions of a higher legal order is established in a way in which the first can be deduced

${ }^{14}$ Advisory Committee understands integration "as a process of social cohesion that respectfully accommodates diversity while promoting a positive sense of belonging for all members of society" (Commentary No. 3: The Language Rights of Persons belonging to National Minorities under the Framework Convention, (further: Commentary No. 3), p. 17, para. 25). 
from the second, hence, ensuring vertical unity of a legal system.

The Framework Convention introduced new standards into the world of minority rights protection. Due to their novel nature, the connection between these standards and the social choices from which they originate is in many of its provisions very palpable. Yet, the Framework Convention is a legal text and in order to serve to legal justice goals, its provisions need to be interpreted in the first place by reference to the higher-ranked legal rules and principles i.e. deduced from the legal premises laid down in the broader framework of international human rights law. In other words, even though the key provisions of the Framework Convention, including Article 15, are of a programmatic character which situates them halfway between law and politics, their normative elaboration is possible only by recourse to the more general legal rules and principles. ${ }^{15}$

This means that to identify the legal objectives behind Article 15 and its standard of adequate representation, we need to depart from the legal expressions of the political notions singled out in the previous section which, as we saw, embody the social values that Article 15 is meant to protect. When placed in the broader framework of the international human rights law, the value of diversity leads us to the right to identity, as guaranteed in Article 27 of the ICCPR. ${ }^{16}$ The value of social inclusion and of fair and democratic institutions can be translated in the principles of equal treatment and non-discrimination, as guaranteed in Article 7 of the Universal Declaration of Human Rights, Article 2. Para. 2 of the International Covenant of the Economic, Social and Cultural Rights and Articles 26 in conjunction with Article 27 of the International Covenant on Civil and Political Rights. This path then brings us to Article 4 and Article 5 of the Framework Convention, as the embodiments of the general principles of equal treatment and non-discrimination and the right to identity in the context of European minority rights law.

\subsection{The relationship between the standard of adequate representation, the principles of equal treatment and non-discrimination and the right to identity}

This comes to no surprise, given that the principles of equal treatment and nondiscrimination and the right to identity are the foundational norms of minority rights protection. ${ }^{17}$ In effect, the Advisory Committee interprets Article 15 in the first place through its relationship with Article 4 and Article 5 of the Convention. In its words, Articles 4, 5 and 15 make up "the three corners of a triangle which together form the main foundations of the Framework Convention" (Commentary No. 2, p. 20, para. 13).

\footnotetext{
${ }^{15}$ A reflection on the advantages of "the administration of justice according to law" in Pound, 1913, p. 709.

${ }^{16}$ For instance, Declaration on the Rights of Persons Belonging to National or Ethnic, Religious and Linguistic Minorities is a direct result of an attempt to create a more effective and comprehensive system for the protection of minority rights by building upon Article 27. See Commentary of the Working Group on Minorities to the United Nations Declaration on the Rights of Persons Belonging to National or Ethnic, Religious and Linguistic Minorities, p. 2, para. 3.

${ }^{17}$ Many authors point to, what they call, the "principle of substantive equality" as the foundational principle of minority protection (Henrard, 2009; Kostadinova, 2011). However, the problem with the notion of "substantive equality" is that it has itself a very indeterminate meaning.
} 
The principles of equal treatment and non-discrimination are in the Framework Convention laid down in Article 4, para. 1, through the guarantees of equality before the law, equal protection of the law and protection against discrimination:

"The Parties undertake to guarantee to persons belonging to national minorities the right of equality before the law and of equal protection of the law. In this respect, any discrimination based on belonging to a national minority shall be prohibited."

Article 4 embraces both formal and de facto equality. The later, as a reflection of the Aristotelian view of justice that equals should be treated equally and those who are unequal unequally, implies non-identical treatment of persons from a minority background to address their differences from the majority population. This is reflection of a broader conception of the equal treatment principle which was tacitly expressed in Thlimmenos v Greece case when the European Court of Human Rights said that "[t]he right not to be discriminated against in the enjoyment of the rights guaranteed under the Convention is also violated when States without objective and reasonable justification fail to treat differently persons whose situations are significantly different" (Judgment, 6 April 2000, para. 44).

As different from the general human rights instruments from which Article 4 can be derived, the minority rights law significantly expands the reach of the principles of equal treatment and non-discrimination by making the proactive measures under certain conditions mandatory and not only permissible (Commentary No. 3, para. 24, p. 17). This ensues from the second paragraph of Article 4 in which the Framework Convention places upon the State Parties a duty to adopt proactive measures when that is indispensable for the full and effective equality of persons belonging to minority communities:

"The Parties undertake to adopt, where necessary, adequate measures in order to promote, in all areas of economic, social, political and cultural life, full and effective equality between persons belonging to a national minority and those belonging to the majority. In this respect, they shall take due account of the specific conditions of the persons belonging to national minorities."

This duty spans a variety of different measures, from affirmative action to reasonable accommodation. Some authors emphasise the importance of reasonable accommodation. Ringelheim, Bribosia \& Rorive (2010, p. 139) note that "where the controversial measure seems the best way to achieve a certain legitimate objective, the adjustment of that measure by means of an exception may be the only way to eliminate the discriminatory character without compromising the measure's purpose". Other authors place an accent on the duty to adopt affirmative measures as a corollary of the prohibition of indirect discrimination (de Vos, 2007, p. 14; Henrard, 2009, p. 556; compare with Tobler, 2008, pp. 51-53). To make the adoption of proactive measures of either kind possible, the drafters of the European Convention in the last paragraph of Article 4 reiterate that the proactive measures should be seen as legitimate means to ensure effective equality of persons of minority origin: 
"The measures adopted in accordance with paragraph 2 shall not be considered to be an act of discrimination."

In the number of its country-specific opinions, the Advisory Committee followed such broad understanding of the principles of equal treatment and prohibition of discrimination while investigating whether and to what extent the State Party concerned has realized the standard of adequate representation of minority communities in public sector. Where the Committee found that persons of minority origin underwent a systematic exclusion from public sector bodies it required from a State Party not only to establish individual grievance mechanisms but also to adopt proactive measures (Opinion on Croatia, p. 14, para. 57). The Committee insisted on the later as well in those cases in which the State Parties concerned claimed that there was a level playing field for all candidates for the positions in public administration bodies, but their public administration workforce was far from reflecting the ethnic complexity of the society (Weller, 2014, p. 283). Given that underrepresentation of persons of minority background in public administration is caused by a mixture of different factors (apart from the cases of direct discrimination), the Advisory Committee is rarely in the position to ascribe underrepresentation to a concrete discriminatory rule or practice. The structural discrimination, which is in the roots of such underrepresentation, cannot be reduced to a single or clearly identifiable source of discrimination, which is yet another reason why in its recommendations the Advisory Committee points to the proactive measures as a response to this phenomenon and a means to fulfil the standard of adequate representation.

The very purpose of proactive measures is to provide for effective equality of persons belonging to minority communities by meeting their special needs. Due to their past discrimination or their characteristics, without these measures the minority groups would not enjoy an equal treatment through the guarantees of formal equality only. The special needs of these groups, which are to be catered through proactive measures, are either consequence of their past or present unequal position with regards to the access to the basic public goods in comparison with the majority population, as an effect of prejudice and/or direct or indirect forms of discrimination, or ensue from the need to preserve their identity which, being different from the identity of majority population, demands additional efforts to be preserved.

This second aspect is elaborated in Article 5 of the Convention, which not only prohibits assimilationist policies or practices (para. 2), but requires the active engagement of the State Parties with the aim to provide the conditions for the preservation of the identity of minority communities:

"The Parties undertake to promote the conditions necessary for persons belonging to national minorities to maintain and develop their culture, and to preserve the essential elements of their identity, namely their religion, language, traditions and cultural heritage (Commentary No. 3, p. 17, para. 24)." 
Article 15 points to the most important way in which the special needs of minority communities are to be met to ensure their effective equality with the majority population. ${ }^{18}$ It provides the means by which "the concerns of persons belonging to minorities regarding full and effective equality, and regarding their right to preservation and development of their specific identity, are heard and effectively taken into account" (Commentary No. 2, p. 21, para. 15). The adequate representation of persons belonging to minority communities in public affairs is one of these means and as such it represents one of the core elements of what some authors call "the participatory equality" established by the Convention (Kostadinova, 2011, p. 177). The participation of persons belonging to minority communities in public affairs and, as such, their effective equality with the members of the majority community, is impossible without their adequate representation in public sector bodies.

To summarise, the analysis of the relationship of Article 15 with Articles 4 and 5 of the Convention shows that the standard of adequate representation of persons of minority origin in public sector bodies serves for the realisation of three specific objectives:

1. To eliminate prejudice against persons belonging to minority communities, which have led to their exclusion or their underrepresentation in the public sector employment;

2. To provide for equal access to the public services for those members of minority communities whose access to these services is impeded by linguistic obstacles or obstacles arising from the specific cultural practices characterising these communities;

3. To ensure that the specific elements of the identity of persons belonging to minority groups, such as minority language, are preserved.

\subsubsection{Elimination of prejudice}

Adequate representation of persons belonging to minority communities in public sector employment is a way to uproot discriminatory attitudes and prejudices towards minority groups. The public sector employment, as different from the private one, is subject to a complex set of merit-oriented requirements and due to its importance for the society at large, it is under continuous public scrutiny (Vukojičić Tomić, 2017, p. 366). The employment of persons belonging to minority communities in public administration sends a strong message of their equal worth and can also serve as model for the private sector employers, thus creating conditions for an improved access of persons of minority origin to the labour market and their more effective participation in the socio-economic life of a country (Vukojičić Tomić, 2017, p. 370). This is particularly applicable to the societies with the high unemployment rate and a significant share of persons working in the black labour market, given that state as an employer in many of these countries engages the significant

${ }^{18}$ For that reason, as already said, the Advisory Committee considers Article 15 to be a central provision of the Framework Convention (Commentary No. 3, p. 53, para. 84). 
portion of a labour force and provides salaried and stable employment. Needless to say, greater participation of persons of minority origin in the public sector employment has positive effects on the social mobility of the members of minority communities (Vukojičic Tomić, 2017, p. 370). In general, the presence of persons who speak minority languages among the public sector employees has an important role in the elimination of prejudices against the minority groups. As noted by Rubio-Marín (2003, p. 64):

"[...] part of the eradication [of prejudice] process will necessarily have to consist in some degree of public accommodation of the languages of the discriminated groups, so that the latter come to be respected as holders of a cultural identity. Only through such accommodation will the speakers of the dominant language, who may have never experienced obstacles of linguistic access themselves, perceive language minorities as more than 'poor speakers' of the dominant language; as people who have their own culture and are in the process of supplementing it with elements of a new one."

\subsubsection{Equal access to public services}

Without adequate representation of persons belonging to minority communities in public sector, the rules, standards, policies and practices for the provision of public services are created without their participation, hence, potentially reflecting only the interests and needs of the majority community. ${ }^{19}$ This might, as a consequence, lead to the situation in which the provision of public services was organised in a way which placed before the minority groups barriers to their equal access to these services and/or resulted in the situation in which these services could not satisfy their specific needs. The Advisory Committee notes that the obstacles to an effective realization of socio-economic rights of persons belonging to minority communities might arise "from the insufficient capacity of the administrations concerned to cater for the specific needs of persons belonging to national minorities" (Commentary No. 2, p. 29, para. 37).

This is especially true for their linguistic needs. Difficulties arising from the asymmetric bilingualism of persons belonging to national minorities i.e. their lack of proficiency in dominant language can negatively affect the realisation of the wide panoply of rights and freedoms (Rubio-Marín, 2003). Here, we are not speaking only about language barriers which may amount to direct or indirect forms of discrimination. "Because language skills are so crucial to functioning in society [...] and to interacting with state authorities", Rubio-Marín notes, "there are many ways in which lack of knowledge of the public and dominant language(s) can diminish people's chances even where this is not

\footnotetext{
${ }^{19}$ For that reason, in its Opinion on Italy, the Advisory Committee praises the Italian legal framework which requires "an adequate representation of the Slovene minority in the bodies drawing up socio-economic and environmental plans so as to safeguard the historic and cultural interests of this minority" (Second Opinion on Italy, p. 31, para. 136). One should, however, be aware of the danger of "symbolic participation" of national minorities in public sector bodies. More on this in Penasa, 2014.
} 
linked to discrimination" (2003, p. 65). The barriers arising from an insufficient command of the language(s) in official use can be part of a broader set of interconnected and mutually reinforcing obstacles which result in a phenomenon of structural discrimination, a form of discrimination which cannot be dissected into concrete discriminatory acts.

The possibility to approach public authorities, especially the public administration bodies, in minority languages is a particularly important aspect of equality through linguistic rights (Palermo, 2007, p. 13). The Advisory Committee observes that "[p]ersons belonging to national minorities frequently face significant difficulties in accessing the labour market, education and training, housing, health care and other social services", often because of "language barriers related to insufficient command of the official language" (Commentary No. 2, p. 54, para 86). These barriers, according to the Committee, are even greater in case of "persons belonging to national minorities who, due to low-quality minority language learning possibilities, graduate with only limited minority language skills and without proficiency in the official language" (Commentary No. 2, p. 54, para. 86). These specific linguistic needs of persons belonging to some minority groups, the Advisory Committee concludes, require that "the effective participation of persons belonging to national minorities and/or speaking minority language(s) is ensured within the administration" (Commentary No. 3, p. 56, para. 89).$^{20}$ A greater representation of minority communities among the public sector workforce facilitates their easier access to the public services, enables the realisation of their socio-economic rights and, in the long run, the overall improvement of their socio-economic position.

\subsubsection{Accommodation of identity-related needs of national minorities}

Although at the first glance, adequate allocation of resources for the acquisition of the dominant language by the linguistic minorities might seem the best road towards their effective participation in public affairs and equal access to public services, this is not enough for the realisation of the participatory rights enshrined in Article 15. "The fact that persons belonging to national minorities also have a command of the German language is not decisive", the Advisory Committee says in its first opinion on Germany, "as the effective use of minority languages remains essential to consolidate the presence of those languages in the public sphere" (Opinion on Germany, 2002, p. 14, para. 49). Language is the basic element of one's identity and the carrier of identity that enables cultural reproduction (Commentary No. 3. p. 5, para. 1). The opportunities to use the language both in private and in public represent an important condition for both material and spiritual wellbeing of linguistic minorities (Packer, 2005, p. 263). A language which is not used in communication with public authorities and in access to public services, "will gradually lose all its terminological potential in that field and become a 'handicapped' language, incapable of expressing every aspect of community life" (Explanatory Report to the European Charter for Regional or Minority Languages, p. 16, para. 101). With

\footnotetext{
${ }^{20}$ See also Fourth Opinion on Finland, p. 32, para. 96.

${ }^{21}$ See, for instance, Fourth Opinion on Moldova, p. 35, para. 97.
} 
that in mind, the Advisory Committee stresses that identity of national minorities can be preserved only through the continuous use of their languages (Commentary No. 3, p. 16, para. 22), both in private and in the public sphere (Commentary No. 3, p. 32, para. 51).

The very fact that language is an essential element of identity and that to be preserved language needs to be practised in private as well as in public, explains why the right to identity enshrined in Article 5, para. 1, mandates its presence in the work of public bodies. Use of minority languages before the administrative authorities is indispensable for "the creation of an overall environment that is conducive to the use of these languages, in order to prevent their disappearance from public life" (Commentary No. 3, p. 17, para. 24). The Committee observes that the provision of conditions for the realisation of linguistic rights through the adequate representation of persons belonging to national minorities and/or speaking the language(s) of national minorities in public administration is not only indispensable for their effective participation in public affairs, but also for the preservation and further development of their identity (Commentary No. 3, p. 5, para. 2).22

The link between the standard of adequate representation of national minorities in public sector and their right to identity has found direct expression in the provision of Article 10, para. 2, which reads as follows:

"In areas inhabited by persons belonging to national minorities traditionally or in substantial numbers, if those persons so request and where such a request corresponds to a real need, the Parties shall endeavour to ensure, as far as possible, the conditions which would make it possible to use the minority language in relations between those persons and the administrative authorities."

For the realisation of the right to use minority languages in dealings with authorities, the Advisory Committee says, the effective participation of persons belonging to national minorities and/or speaking minority language(s) through their recruitment, promotion and retention need to be ensured within administration (Commentary No. 3, p. 56, para. 89). ${ }^{23}$ Although at the first reading this might sound as if the national authorities were under the duty to secure the given right only if persons belonging to minority communities had no command of the official language, the scope of Article 10, para. 2 is actually much wider. According to the Advisory Committee it also encompasses the need to preserve minority languages:

"Need' in this context does not imply the inability of persons belonging to national
minorities to speak the official language and their consequent dependence on ser-
vices in their minority language. A threat to the functionality of the minority lan-

22 This ensues, in the first place, from the identity-related needs of minority groups. There are, however, number of theories which build the case for linguistic rights not because of minority groups and their needs but in the name of the goal of preservation of linguistic diversity which is postulated in a similar fashion as the goal of preserving biodiversity. An overview and critical observation of such an approach to linguistic rights in Boran, 2003. An interesting discussion on the linguistic rights based on the conception of language as a public good in Van Parijs, 2003.

${ }^{23}$ See also, Second Opinion on Albania, p. 37, para. 209. 
guage as a communication tool in a given region is sufficient to constitute a 'need' in terms of Article 10.2 of the Framework Convention. Protective arrangements must be in place to maintain services in the minority language, even if it is not widely used, as it may otherwise disappear from the public sphere" (Commentary No. 3, p. 35 , para. 56).

Such a broad understanding of "need" in the context of Article 10 confirms the conclusion that the rationale of the standard of adequate representation is to be found both in the removal of linguistic barriers to an equal access to public services for the members of minority groups, as well as in providing the conditions for the preservation of their minority identity through the preservation of their language. The fulfilment of these two, eventually, also leads to the fulfilment of the objective of eradication of prejudice, as a consequence of the strong interrelatedness of the three above-identified objectives of the standard of adequate representation of persons of minority origin in public sector bodies.

\section{Conclusion}

Article 15 of the Framework Convention is an attempt to serve at the same time both representational and socio-economic equality claims of national minorities and in that way overcome the dichotomy between their recognition and redistribution related needs. Whether and to what extent such an approach can bring significant improvements of the position of European minority groups vis-à-vis the majority population cannot be assessed without a suitable benchmark to measure the level of fulfilment of Article 15. The Advisory Committee to the Framework Convention has been using the standard of adequate representation to evaluate the degree of implementation of Article 15 participatory rights, but some aspects of the standard have remained underdeveloped. This is, in particular, the case with the subtype of the standard of adequate representation which concerns the participation of persons of minority origin in the work of public administration and other segments of the public sector. Due to the novelty of this particular duty and the programmatic character of Article 15, the standard of adequate representation of persons belonging to minority communities in public sector bodies has so far remained almost as vague as the duty the implementation of which it is supposed to measure. Neither the legal theory nor the practice of the Advisory Committee has so far managed to bring an additional dose of certainty to the standard and, hence, increase its interpretative value, even though that there is a clear need to give additional guidance to the State Parties with regards to this particular strand of Article 15.

The paper departs from the premise that further normative elaboration of the standard requires a clearer understanding of what are the objectives to be achieved by the adequate representation of persons belonging to national minorities in public sector bodies. The mainstream human and minority rights discourse is dominated by the notions of diversity, social inclusion, social cohesion, fair and democratic governance, etc. to the point that the question of objectives behind the standard of adequate representation 
sounds redundant. These notions also act as the explanatory dogmas in the Advisory Committee's interpretations of the objectives behind Article 15 and the standard of adequate representation. Although the notions of diversity, social cohesion, good governance, etc. have an important rhetorical function in the minority rights discourse, they cannot usher further development of the normative content of the standard of adequate representation, nor could they guide the practice of the State Parties.

With that in mind, in the paper these social ideals are translated into their legal expressions found in the right to equal treatment and non-discrimination and the right to identity, which are then analysed as the main determinants of the objectives behind the standard of adequate representation. Through an investigation of the relationship between the standard of adequate representation and these two rights (Articles 4 and 5 of the Framework Convention), three principal legal objectives behind the standard of adequate representation have been established: elimination of prejudice, equal access to public services and accommodation of identity-related needs of national minorities. Adequate representation of persons belonging to minority communities in the public sector should serve to uproot discriminatory attitudes and prejudices towards minority groups. The legal rationale of the standard of adequate representation is also in the removal of linguistic and other obstacles to equal access to public services for the members of minority groups, and in providing the conditions for the preservation of their minority identity through the preservation of their language and other elements of their culture. The three objectives are interrelated to the point that a greater level of fulfilment of one objective also leads to the greater fulfilment of the other two objectives.

The identification of the legal objectives behind the standard of adequate representation surely does not bring answers to all the questions arising from the application of the standard. Yet, a deeper insight into the goals to be realized can help to minority communities and governments to have a clearer view of the claims which can be reasonably made and of the reasonable means which are at their disposal to implement this strand of Article 15. While it is true that an awareness of the ends to be achieved does not point to the best means, by identifying these ends we have covered at least part of the distance towards a better understanding of what does it take to fulfil the standard of adequate representation of persons belonging to national minorities in public sector bodies.

\section{References}

Basta Fleiner, R. L. 2013. Participation Rights Under the Framework Convention for the Protection of National Minorities (FCNM): Towards a Legal Framework Against Social and Economic Discrimination. Zbornik radova Pravnog fakulteta u Nišu, 65, pp. 19-36.

Baude, W. \& Sachs, E. S. 2017. The Law of Interpretation. Harvard Law Review, 130, pp. 1079-1147.

Boran, I. 2003. Global Linguistic Diversity, Public Goods, and the Principle of Fairness. In: Kymlicka, W. \& Patten, A. (eds.). Language Rights and Political Theory. Oxford: 
Oxford University Press, pp. 189-209.

Brink, O. D. 1998. Legal Theory, Legal Interpretation, and Judicial Review. Philosophy \& Public Affairs, 17(2), pp. 105-148.

De Vos, M. 2007. Beyond Formal Equality: Positive Action under Directives 2000/43/EC and 2000/78/EC. Luxembourg: Office for Official Publications of the European Communities.

Dworkin, R. 1977. Taking Rights Seriously. Cambridge (MA): Harvard University Press.

Economides, C. 2010. Content of the Obligation: Obligations of Means and Obligations of Result. In: Crawford, J., Pellet, A. \& Olleson, S. (eds.). The Law of International Responsibility. Oxford: Oxford University Press, pp. 371-382.

Fraser, N. 1997. Justice Interruptus: Critical Reflections on the "Postsocialist" Condition. New York: Routledge.

Greenberg, M. 2017. What Makes a Method of Legal Interpretation Correct? Legal Standards Vs. Fundamental Determinants. Harvard Law Review Forum, 130(4), pp. 105-126.

Henrard, K. 2009. Minorities and Socio-Economic Participation: Two Pillars of Minority Protection Revisited. International Journal on Minority and Group Rights, 16, pp. 549-576.

Joseph, M. 2009. Effective Participation of National Minorities in Public Affairs in Light of National Case Law. International Journal on Minority and Group Rights, 16, pp. 621-642.

Kostadinova, G. 2011. Minority Rights as a Normative Framework for Addressing the Situation of Roma in Europe. Oxford Development Studies, 39(2), pp. 163-183.

Malloy, H. T. et al. 2009. Indicators for Assessing the Impact of the FCNM in its State Parties (Draft Study). Conference: Enhancing the Impact of the Framework Convention. 9-10 October 2008. Strasbourg: European Academy Bolzano, Institute for Minority Rights. Malloy, H. T. \& Wolf, S. 2016. Linguistic Minority Rights in the Danish-German Border Region: Reciprocity and Public Administration Policies. International Journal on Minority and Group Rights, 23, pp. 485-504.

Moore, N. J. 1969. The Control of Foreign Intervention in Internal Conflict. Virginia Journal of International Law, 9(2), pp. 205-342.

OSCE High Commissioner on National Minorities. 1999. The Lund Recommendations on the Effective Participation of National Minorities in Public Life. The Hague: High Commissioner on National Minorities.

OSCE High Commissioner on National Minorities. 2012. The Ljubljana Guidelines on Integration of Diverse Societies \& Explanatory Note. The Hague: High Commissioner on National Minorities.

Palermo, F. 2007. Legal Solutions to Complex Societies: The Law of Diversity. In: Ruiz Vieytez, E. J. \& Dunbar, R. (eds.). Human Rights and Diversity: New Challenges for Plural Societies. Bilbao: University of Deusto, pp. 63-82.

Packer, J. 2005. The OSCE High Commissioner on National Minorities: Pyrometer, Prophylactic, Pyrosvestis. In: Ghanea, N. \& Xanthaki A. (eds.). Minorities, Peoples and Self-Determination. Leiden: Martinus Nijhoff Publishers, pp. 249-268. 
Patten, A. 2005. The Rights of Internal Linguistic Minorities. In: Eisenberg A. \& SpinnerHalev, J. (eds.). Minorities within Minorities: Equality, Rights and Diversity. Cambridge: Cambridge University Press, pp. 135-154.

Penasa, S. 2014. From Protection to Empowerment Through Participation: The Case of Trentino - a Laboratory for Small Groups. Journal on Ethnopolitics and Minority Issues in Europe, 13(2), pp. 30-53.

Phillips, A. 2009. Contribution of the Council of Europe Framework Convention for the Protection of National Minorities and its Advisory Committee to the Effective Participation Rights of National Minorities. International Journal on Minority and Group Rights, 16, pp. 527-537.

Pound, R. 1913. Justice According to Law. Columbia Law Review, 13(8), pp. 696-713.

Ringelheim, J., Bribosia, E. \& Rorive, I. 2010. Reasonable Accommodation for Religious Minorities: A Promising Concept for European Antidiscrimination Law?. Maastricht Journal of European and Comparative Law, 17(2), pp. 137-161.

Rubio Marin, R. 2003. Language Rights: Exploring the Competing Rationales. In: Kymlicka, W. \& Patten, A. (eds.). Language Rights and Political Theory. Oxford: Oxford University Press, pp. 52-79.

Tobler, C. 2008. Limits and Potential of the Concept of Indirect Discrimination. Luxembourg: Office for Official Publications of the European Communities.

Vacca, A. 2016. Rights to Use Minority Languages in the Public Administration and Public Institutions: Italy, Spain and the UK. Torino: Giappichelli.

Van Parijs, P. 2003. Linguistic Justice. In: Kymlicka W. \& Patten A. (eds.). Language Rights and Political Theory. Oxford: Oxford University Press, pp. 153-168.

Venice Commission 2011. The Participation of Minorities in Public Life (Science and Technique of Democracy No. 45). Strasbourg: Council of Europe Publishing.

Verstichel, A. 2004. Elaborating a Catalogue of Best Practices of Effective Participation of National Minorities: Review of the Opinions of the Advisory Committee Regarding Article 15 of the Council of Europe Framework Convention for the Protection of National Minorities. European Yearbook of Minority Issues, 2, pp. 165-195.

Vukojičić Tomić, T. 2017. Suvremeni pristupi i modeli zapošljavanja društvenih manjina u javnoj upravi. Hrvatska i komparativna javna uprava, 17, pp. 365-388.

Weller, M. 2004. Creating the Conditions Necessary for the Effective Participation of Persons Belonging to National Minorities. International Journal on Minority and Group Rights, 10, pp. 265-290.

\section{Website references}

Roter, P. 2015. Additional Opinion on the Action Plan for the Realisation of the Rights of National Minorities of the Republic of Serbia. Available at: https://pjp-eu.coe.int/en/ web/minority-rights/images/additional\%20opinion\%20on\%20the\%20action\%20 plan\%20and\%20the\%20revised\%20action\%20plan\%20from\%2020\%20january\%20 2016\%20-\%20dr\%20petra\%20roter.pdf (accessed on ${ }^{\text {st }}$ September 2019). 


\section{Legal sources}

Advisory Committee on the Framework Convention for the Protection of National Minorities, Commentary No. 2: The Effective Participation of Persons Belonging to National Minorities in Cultural, Social and Economic Life and in Public Affairs, ACFC/31DOC(2008)001 (adopted on 27 February 2008).

Advisory Committee on the Framework Convention for the Protection of National Minorities, Opinion on Cyprus, ACFC/INF/OP/I(2002)4 (adopted on 6 April 2001). Advisory Committee on the Framework Convention for the Protection of National Minorities, Opinion on Croatia, ACFC/INF/OP/I(2002)003 (adopted on 6 April 2001).

Advisory Committee on the Framework Convention for the Protection of National Minorities, Opinion on Germany, ACFC/INF/OP/I(2002)008 (1 March 2002).

Advisory Committee on the Framework Convention for the Protection of National Minorities, Opinion on the Netherlands, ACFC/OP/I(2009)002 (adopted on 17 February 2010).

Advisory Committee on the Framework Convention for the Protection of National Minorities, Second Opinion on Albania, ACFC/OP/II(2008)003 (adopted on 29 May 2008).

Advisory Committee on the Framework Convention for the Protection of National Minorities, Second Opinion on Bosnian and Herzegovina, ACFC/OP/II(2008)005 (adopted on 9 October 2008).

Advisory Committee on the Framework Convention for the Protection of National Minorities, Second Opinion on Italy, ACFC/INF/OP/II(2005)003 (adopted on 24 February 2005).

Advisory Committee on the Framework Convention for the Protection of National Minorities, Second Opinion on Kosovo*, ACFC/OP/II(2009)004 (adopted on 5 November 2009).

Advisory Committee on the Framework Convention for the Protection of National Minorities, Second Opinion on Serbia, ACFC/OP/II(2009)001 (adopted on 19 March 2009).

Advisory Committee on the Framework Convention for the Protection of National Minorities, Third Opinion on Estonia, ACFC/OP/III(2011)004 (adopted on 1 April 2011).

Advisory Committee on the Framework Convention for the Protection of National Minorities, Third Opinion on Italy, ACFC/OP/III(2010)008 (adopted on 15 October 2010).

Advisory Committee on the Framework Convention for the Protection of National Minorities, Third Opinion on Kosovo*, ACFC/OP/III(2013)002 (adopted on 6 March 2013).

Advisory Committee on the Framework Convention for the Protection of National Minorities, Third Opinion on Montenegro, ACFC/OP/III(2019)001rev (adopted on 7 March 2019).

Advisory Committee on the Framework Convention for the Protection of National Minorities, Third Opinion on Serbia, ACFC/OP/III(2013)006 (28 November 2013). 
Advisory Committee on the Framework Convention for the Protection of National Minorities, Fourth Opinion on Croatia, ACFC/OP/IV(2015)005rev (adopted on 18 November 2015).

Advisory Committee on the Framework Convention for the Protection of National Minorities, Fourth Opinion on Finland, ACFC/OP/IV(2016)002 (adopted on 24 February 2016).

Advisory Committee on the Framework Convention for the Protection of National Minorities, Fourth Opinion on Kosovo*, ACFC/OP/IV(2017)001 (adopted on 8 March 2017).

Advisory Committee on the Framework Convention for the Protection of National Minorities, Fourth Opinion on Moldova, ACFC/OP/IV(2016)004 (adopted on 25 May 2016).

Advisory Committee on the Framework Convention for the Protection of National Minorities, Fourth Opinion on North Macedonia, ACFC/OP/IV(2016)001 (adopted on 24 February 2016).

Advisory Committee on the Framework Convention for the Protection of National Minorities, Fourth Opinion on Norway, ACFC/OP/IV(2016)008 (adopted on 13 October 2016).

Advisory Committee on the Framework Convention for the Protection of National Minorities, Fourth Opinion on the Slovak Republic, ACFC/OP/IV(2014)004 (adopted on 3 December 2014).

Advisory Committee on the Framework Convention for the Protection of National Minorities, Fourth Opinion on Serbia, ACFC/OP/IV(2019)001 (adopted on 26 June 2019).

Explanatory Report to the European Charter for Regional or Minority Languages, European Treaty Series No. 148, Strasbourg (5 October 1992).

Explanatory Report to the Framework Convention for the Protection of National Minorities, European Treaty Series No. 157, Strasbourg (1 February 1995).

Framework Convention for the Protection of National Minorities, CoE ETS No. 157 (1 February 1995).

International Covenant on Civil and Political Rights, United Nations Treaty Series, vol. 999, (23 March 1976), p. 171.

Thlimmenos $v$ Greece (6 April 2000), Judgment (Preliminary objection, merits and just satisfaction), App. No. 34369/97, ECHR 2000-IV, (2001) 31 EHRR 411, IHRL 2928 (ECHR 2000).

UN Human Rights Committee, General Comment No. 25: Article 25 (Participation in Public Affairs and the Right to Vote), The Right to Participate in Public Affairs, Voting Rights and the Right of Equal Access to Public Service, CCPR/C/21/Rev.1/ Add.7, (12 July 1996).

UN Sub-Commission on the Promotion and Protection of Human Rights, Commentary of the Working Group on Minorities to the United Nations Declaration on the Rights of Persons Belonging to National or Ethnic, Religious and Linguistic Minorities, E/ CN.4/Sub.2/AC.5/2005/2 (adopted on 4 April 2005). 


\title{
Dr Milica V. Matijević
}

Naučni saradnik, Institut za uporedno pravo, Beograd, Srbija

e-mail:milicavmatijevic@gmail.com

\section{KA BOLJEM RAZUMEVANJU STANDARDA ADEKVATNE ZASTUPLJENOSTI PRIPADNIKA NACIONALNIH MANJINA U JAVNOM SEKTORU}

\author{
Sažetak
}

Članom 15 Okvirne konvencije nalaže se državama članicama da stvore uslove potrebne za delotvorno učešće pripadnika nacionalnih manjina u radu državne uprave i drugim segmentima javnog sektora. Kao što je to slučaj i sa ostalim elementima čl. 15, stepen ispunjenosti ove obaveze ocenjuje se spram standarda adekvatne zastupljenosti. Obaveza obezbeđenja uslova za adekvatnu zastupljenost pripadnika nacionalnih manjina $\mathrm{i} /$ ili osoba koje govore manjinske jezike u javnom sektoru predstavlja novinu u načinu organizacije javne uprave jer su sve do donošenja Okvirne konvencije one po pravilu bile jednojezične. To, kao i okolnost da su odredbe čl. 15 programatskog karaktera, dovodi do izražene neodređenosti standarda adekvatne zastupljenosti. U radu autorka pristupa ovom problemu kroz nastojanje da identifikuje pravne ciljeve koje treba ostvariti primenom standarda adekvatne zastupljenosti pripadnika nacionalnih manjina u javnom sektoru, te sa tim naumom analizira tematske komentare i pojedinačna mišljenja Savetodavnog komiteta za Okvirnu konvenciju. Svrha rada je da se kroz potpunije razumevanje pravnih ciljeva koji leže u temelju standarda adekvatne zastupljenosti doprinese njegovom daljem normativnom elaboriranju. Ovo je neophodno kako bi standard postao određeniji i jasniji, te time i korisniji kako državama članicama Okvirne konvencije u njihovim nastojanjima da ispune obavezu stvaranja uslova za delotvorno učešće pripadnika nacionalnih manjina u radu javnog sektora, tako i samom Savetodavnom komitetu prilikom procene stepena ispunjenosti čl. 15.

Ključne reči: čl. 15, standard adekvatne zastupljenosti, tela javne uprave, Savetodavni komitet, nacionalne manjine.

Article history:

Received: 17 January 2020

Accepted: 27 January 2020 